\title{
Application of POE (Predict-Observe-Explain) Learning Strategies to Reduce Students' Misconceptions in Science Subjects in Elementary School
}

\author{
Dani Tri Astiti, \\ Postgraduate Student, \\ Primary Education of Study Program, \\ Universitas Negeri Surabaya
}

\author{
Muslimin Ibrahim \\ Professor of Biology Education (Science Education), \\ Universitas Negeri Surabaya
}

\author{
Eko Hariyono \\ Dr. of Science Education, \\ Faculty of Mathematics and Natural Science, \\ Universitas Negeri Surabaya
}

\begin{abstract}
Concept is a very important part in the process of acquiring knowledge in various studies including science. The reality, students have not mastered the concept of science properly or have a different initial conception with the correct concept so that it has difficulty in using the concepts possessed to explain various kinds of natural phenomena in daily life. The purpose of this study is to describe that the Predict-Observe-Explain strategy can reduce student's misconceptions in elementary school. This research includes a Pre-Experiment research with One Group Pretest-Posttest Design. The subjects in this study were students of class V SDN Krembangan Selatan I Surabaya with a total of 12 children in a limited test. Data analysis techniques using quantitative descriptive analysis. The results showed that (1) the conception profile before learning with the POE strategy obtained an average of $67 \%$ of all research subjects had misconceptions for each concept item. (2) the conception profile after learning with the POE strategy obtained an average of $7.4 \%$ of all research subjects have misconceptions for each concept item (3) learning to use POE strategies can reduce student's misconceptions on science subjects material force and motion, characteristics of living things, and objects or materials.
\end{abstract}

Keywords:- misconception, POE, Strategy.

\section{INTRODUCTION}

Natural Sciences (IPA) is one of the subjects that must be studied at the elementary school level. Science education encourages students to study themselves and the natural environment more deeply, rationally, and scientifically. According to Sulistyorini (2007: 9), in essence Natural Science consists of three components namely the scientific process, scientific attitude, and scientific products. First, science as a process (method), views that science has a dynamic nature, like a wheel that always rotates in the context of developing science in accordance with the existing reality. generalizations that can strengthen, revise, or even reject theories that have previously existed in the product of science. Second, science as an attitude requires students to have behavior that reflects the attitude of people who are knowledgeable, honest, conscientious, confident, responsible, and also discipline. Third, science as a product consists of laws, principles, theoretical procedures, concepts, facts and information. The concept is a product of the scientific process, which is the smallest component of science. Therefore, the concept as one of the products of science becomes very important because it is the basic material to build various theories, laws, principles, or procedures in science itself.

The description of Natural Sciences as above, shows that the concept has a strategic position in determining the validity of Natural Sciences, because the concept of building other scientific products such as theory and law. That is why teaching science concepts must be done in such a way. The teaching of science concepts is well designed so that concept errors do not occur. Some experts try to make a "guide" how the learning process of science, so that misconceptions do not occur.

Kubiatko (2007: 12), from a constructivism perspective, learning is an active process, in which students 'take' information from the surrounding environment and then build personal interpretations and meanings based on prior knowledge and experience. Ausubel in Dahar (2011: 95) states that learning is said to be meaningful if the information to be learned by students is arranged according to the cognitive structure owned by students so that students can associate new information with the cognitive structure they have. There are three benefits of meaningful learning, namely; 1) Information learned meaningfully longer can be remembered; 2) Information learned meaningfully facilitates subsequent learning processes for similar subject matter; 
Elementary school students get the concept through a variety of learning processes that occur not only at school, but can also at home and even the community environment that tends not to pay attention to the results optimally, for example in terms of the truth of the concept. The assumption is that students have not mastered the concepts of natural science well or have an initial conception that is not the same as the actual concept so that it has difficulty in using the concepts possessed to explain various kinds of natural phenomena in daily life. Too bad the facts on the ground show that there was a concept error. This can happen one of them because students not only learn concepts from the teacher in the classroom, but also learn from other learning resources both with the help of others and independently.

Misconceptions that occur in students can be caused by several causes, namely the condition of students when accepting concepts, teachers who teach already have concepts that are not in accordance with the truth of the concept, learning methods, and books and context (Suparno, 2005: 54). In line with this statement, Ibrahim (2012: 14) states that some things that can cause misconceptions are (1) mastery of students' concepts that are incomplete, simple, even different, (2) the inability of students to distinguish the characteristics of a concept, (3) students do not master the prerequisite concepts of a particular concept, (4) the number of relevant and irrelevant attributes, (5) colloquial terms or mother language that is not appropriate, (6) learning resources that are not appropriate, (7) background behind learners. In general, the causes of students' misconceptions come from two factors, namely internal factors and external factors. Internal factors come from within the students, for example the condition of students when carrying out learning. While external factors come from outside the students themselves, for example the application of learning strategies and methods, concept errors that are first experienced by teachers, as well as books or learning references that are not in accordance with the correct concepts.

There are several alternative choices to identify the occurrence of misconceptions in students, one of which is a three-tier diagnostic test. Pesman (2010: 216) argues that the three-tier diagnostic test is the most valid, reliable and accurate test instrument for identifying students' misconceptions. This three-tier based diagnostic test is a test that consists of three levels of questions. The first level (first-tier) in the form of answer choice questions, the second level (second-tier) in the form of choice reasons for questions at the first level, and the third level (third-tier) in the form of affirmation questions about the beliefs of the answers that have been selected at level one and two. Through the use of a three tier diagnostic test, researchers will obtain more information about students 'misconceptions and can determine the category of students' responses to the proposed concept statement. As written by Mubarokah, Febriati Dian, et al (2018: 52), four categories of learner understanding that can later be obtained through the application of the Three Tier Diagnostic Test include:
(1) understanding the concept; (2) lack of concepts; (3) misconceptions; and (4) Error.

Researchers had the opportunity to conduct a preliminary study at SDN Krembangan Selatan I, through observation and also the implementation of tests, the researchers found that students in grade $\mathrm{V}$ at the school experienced a misconception on the subject of natural sciences, namely the characteristics of living things, forces and motion, and objects or materials. Researchers used the Three-tier Diagnostic Test instrument to identify the misconception. After being tested on 12 grade $\mathrm{V}$ students, the results of the analysis showed that there were misconceptions on the materials mentioned earlier. The facts show that there has been a misconception in the field. Therefore, efforts must be made to correct the mistakes that have occurred so as not to drag on.

In fact, many misconceptions occur in various spheres of learning study material in elementary schools. As is the case with students in class V in SDN Krembangan Selatat. Misconceptions occur in some natural science materials including force and motion, characteristics of living things, and objects or materials. In material characteristics of living things for example, students experience a misunderstanding of the concept between hair and hair. They mention that rabbits or cats are furry animals. This is also supported by reference books that are not in accordance with the correct concept. Similarly, various other concepts that students often misunderstand. They are accustomed to everyday terms like gecko feet made of adhesive liquid so that it can stick to the wall, or they think the dots of water that are outside the glass wall of ice come from inside the glass. They experience wrong preconceptions or even experience misconceptions without knowing the true concept.

Referring to the causes of misconception mentioned above, one way that can be chosen to overcome them is through the selection of appropriate learning strategies. The learning strategy chosen is expected to make the process of acquiring concepts more meaningful and not just accept them.

According to Ibrahim (2012: 47-57), ways that can be used to correct misconceptions that occur in students or minimize misconceptions that will occur when learning takes place, among others, by Conceptual Change (Conceptual Changed), Cognitive Conflicts, Contructivism, POE (Predictions) -Observe-Explain), and PDEODE (Predict-Discuss-Explain-Observe-Discuss-Explain). Liew and Treagust (1995: 71), in their research concluded that POE learning strategies can create opportunities for students to reconstruct and change their previous conceptions as a result of inconsistencies and contradictions between observations and predictions. Similarly, Banawi, et al (2019: 369) which writes that the results of applying POE learning strategies in his research can change the conception of both teachers and students in accordance with existing scientific concepts. Halim, Yong, and Mohd Meerah (2014: 1037) in their research showed that the application of active learning strategies, where students do 
not just listen to lectures, can help students to understand concepts more meaningfully and can effectively overcome their misconceptions. This is because during the learning process they can find, process, and apply the information they get in their daily lives. where students do not just listen to lectures, can help students to understand concepts more meaningfully and can effectively overcome their misunderstandings. This is because during the learning process they can find, process, and apply the information they get in their daily lives. where students do not just listen to lectures, can help students to understand concepts more meaningfully and can effectively overcome their misunderstandings. This is because during the learning process they can find, process, and apply the information they get in their daily lives.

The researcher chose POE strategy to change the concept errors that occurred in class V SDN Krembangan Selatan I. Based on what was explained by Adebaya, et al $(2015,88)$ that POE is an effective learning strategy for making ideas or initial ideas of students and doing activities observation and discussion, then explain the findings of the concepts they have learned. The POE strategy has the following stages, namely predictions, observations, and explanations.

Some educational research shows that students will learn better when they build their own understanding with scientific ideas in order to understand existing knowledge both through observation activities and direct experiments. To achieve this process, students must be able to learn from that involvement, so that appropriate strategies and methods are needed to be able to foster student activity. One learning strategy that can be applied is the POE learning strategy. For example, a study conducted by Ramon Sinkiriwang Putrama (2015), showed an increase in students' understanding of concepts by $47.27 \%$ by implementing POE learning strategies as a solution. The results of research conducted by Bayram Costu, Alipasa Ayas, and Mansoor Niaz (2011) which states that learning strategies based on POE can help students to understand the concept of condensation better and allow students to remember concepts in their long-term memory. Restami, et al (2010) conducted a study with the results that there were differences in understanding physical concepts and scientific attitudes of students between groups of students who studied with the POE model and conventional learning models. Rohmad's research (2013) concluded that learning tools developed with POE strategies can reduce scientific misconceptions. Another study with the same strategy is the research conducted by Lusandra Dewi Lestari (2018), which also shows that learning activities using POE strategies have significantly reduced misconceptions.

Referring to some of the studies mentioned above, researchers intend to apply the same strategy, namely POE, to reduce students' misconceptions encountered in the field. The difference from the research conducted by researchers when compared with previous studies that are in terms of the material being tested. The researcher will examine concepts in the matter of force and motion, the characteristics of living things, and objects or materials.

Based on this background, the researchers intend to carry out research with the title "Implementation of POE (Predict-Observe-Explain) Learning Strategies to Reduce Students' Misconceptions in Science Subjects in Primary Schools".

\section{THEORETICAL FRAMEWORK}

\section{A. Misconception}

The concept is a very small part of information, the main constituent in the formation of scientific knowledge and human thought. The concept is an abstraction of objects or events that are unique and meaningful. The concept can contain information if it has a relationship or a relationship with another concept (Berg, 1991: 8) in line with this, Woodruf (in Ibrahim, 2012: 2) defines the concept is a meaningful idea, gives meaning to an object, subjective products that are comes from a person's understanding of what he has experienced. Ibrahim (2012: 3) explains that the concept is a collection of stimulus in the form of facts, objects, events, and others that have the same attributes, so that makes it different from the others. Attributes are characteristics that distinguish examples from concepts and not examples from concepts. So it can be concluded that the concept is an abstract representation in the form of facts, objects, events, and others that have attributes (characteristics) so that they differ from one another.

Student misconceptions are students' conceptions about certain concepts that are not in accordance with concepts understood by scientists (Berg, 1991: 10). Hammer (in Tayubi, 2005: 5) defines misconception as "strongly held cognitive structures that are different from the accepted understanding in a field and that the presume to interfere with the acquisition of new knowledge" which means that misconceptions are knowledge structures that adhere strongly to in someone's view which is not in accordance with the conceptions held by scientists. Meanwhile, according to Ibrahim (2012: 13) defines misconception as a person's ideas or views that are not true about a concept even completely different from the views of experts or scientists, where this view is resistant and persistent. So it can be concluded that misconception is an incorrect understanding of the concept both in terms of labels, definitions, attributes, examples, and values. So it will be very prone to chaos and multiple interpretations if the concept that is not true will be associated with other concepts in an information.

Misconception is caused by two things, namely internal and external factors. Internal factors are caused by the condition of students when receiving learning which affects the understanding of the concepts they will receive later. For example, seen from the ability or way of thinking, stages of cognitive development, interest in learning, reasoning that is not sticky, or wrong intuition. While external factors come from outside the students themselves, 
for example from teachers or educators, learning methods, books or references, as well as students' backgrounds.

Identification of misconceptions experienced by students in this research using three-tier diagnostic test Prodjosantoso, et al (2019: 1478) in his research stated that this three-tier diagnostic test serves to reveal students' understanding completely, this test can determine the level of student misunderstanding, including reason and also level of trust. That way, researchers will get more information about students 'misconceptions and can determine the category of students' responses to the proposed concept statement, namely students who understand the concept, do not understand the concept, or misconceptions.

\begin{tabular}{|c|c|c|c|}
\hline $\begin{array}{c}\text { First } \\
\text { tier }\end{array}$ & Second tier & Third tier & Category \\
\hline Right & Sure & $\begin{array}{c}\text { Right / } \\
\text { Scientific }\end{array}$ & $\begin{array}{l}\text { Understand the } \\
\text { Concept }\end{array}$ \\
\hline Right & Not sure & $\begin{array}{c}\text { Right / } \\
\text { Scientific }\end{array}$ & \multirow{4}{*}{ Lack of Concept } \\
\hline Right & Not sure & False & \\
\hline False & Not sure & $\begin{array}{c}\text { Right / } \\
\text { Scientific }\end{array}$ & \\
\hline False & Not sure & False & \\
\hline False & Sure & $\begin{array}{c}\text { Right / } \\
\text { Scientific }\end{array}$ & Error \\
\hline Right & Sure & False & \multirow{2}{*}{ Misconception } \\
\hline False & Sure & False & \\
\hline
\end{tabular}

(Kaltakci, 2007)

Table 1:- Guidelines for Evaluating Student Answers

\section{B. POE Strategy}

One strategy to correct misconceptions according to Ibrahim (2012: 52) is POE namely Predict (P), Observe (O), and Explain (E). This strategy begins with prediction activities carried out by students of a good concept of an object, event, and others. Students predict answers to their thinking. Then the predictions they have conveyed are confronted with the facts that occur. This fact is obtained through observations made both individually and in groups. And at the last stage that is formulating an explanation based on the results of observations that have been made. The benefits of applying POE learning strategies are written by Ogunleye and Babajide (2010: 15) that students are encouraged to develop their own ideas, identify their conceptions and misconceptions with the help of teachers in various subjects including science. Correspondingly, Gernale and Aranes (2015: 18) also explained that the application of POE learning strategies can increase motivation to learn, significantly increase academic achievement of students, students become easier in understanding scientific concepts, able to use them effectively in daily life day. Adebaya, et al $(2015,88)$ also explained that POE learning strategies are very efficient at generating students' ideas because this learning strategy involves students directly to predict and then observe their own phenomena until finally they are able to explain the differences that arise between their initial predictions and observation. 18) also explained that the application of POE learning strategies can increase learning motivation, significantly increase students' academic achievement, learners become easier in understanding scientific concepts, able to use them effectively in daily life. Adebaya, et al $(2015,88)$ also explained that POE learning strategies are very efficient at generating students' ideas because this learning strategy involves students directly to predict and then observe their own phenomena until finally they are able to explain the differences that arise between their initial predictions and observation. 18) also explained that the implementation of POE learning strategies can increase learning motivation, significantly increase students' academic achievement, learners become easier in understanding scientific concepts, able to use them effectively in daily life. Adebaya, et al $(2015,88)$ also explained that POE learning strategies are very efficient at generating student ideas because this learning strategy involves students directly to predict and then observe their own phenomena until finally they are able to explain the differences that arise between their initial predictions and observation. able to use it effectively in everyday life. Adebaya, et al $(2015,88)$ also explained that POE learning strategies are very efficient at generating students' ideas because this learning strategy involves students directly to predict and then observe their own phenomena until finally they are able to explain the differences that arise between their initial predictions and observation. able to use it effectively in everyday life. Adebaya, et al $(2015,88)$ also explained that POE learning strategies are very efficient at generating student ideas because this learning strategy involves students directly to predict and then observe their own phenomena until finally they are able to explain the differences that arise between their initial predictions and observation.

\section{Study of Natural Sciences Learning in Primary Schools \\ In accordance with the theory of cognitive} development conveyed by Piaget, students at the age of elementary school are at a concrete operational stage that is in the age range of 7 years to 12 years. The ability that appears in this phase is the ability in the process of thinking to operate the rules of logic, although they are still bound by concrete objects. Characteristics of individual development at this stage, namely, children begin to be able to use rules clearly and logically. The learning process and development of elementary school children have a tendency to start in concrete terms, seeing what they learn is an integrated need and through a manipulative process. Learning in primary schools must be planned, then implemented, and finally assessed based on trends based on the above explanation.

Furthermore, Vygotsky (in Lestari, 2018: 32) argues that cognitive change occurs when concepts that have been previously understood by individuals are then reprocessed through an imbalance process in order to understand new information. The process of assimilation and 
accommodation in each individual's cognitive development is at the core of Piaget's constructivist theory. Through assimilation, students enter new information and combine it into existing cognitive structures / schemes. While in the process of accommodation, students change their cognitive structure to match the new information meaning, they use their concepts to deal with new phenomena and then replace the wrong concepts by forming new patterns that fit with new experiences.

The stages that exist in the POE learning strategy that will be implemented in learning, especially in the second stage namely observe will be a core stage that can facilitate the process of assimilation and accommodation of concepts that will later be formed in the cognitive structure of students.

This research focuses on several concepts related to force and motion material, objects or materials, and the characteristics of living things. For more details, the following will be described several misconceptions experienced by students that will be presented in the following table:

\begin{tabular}{|c|c|}
\hline Moving air has a greater pressure than silent air. & $\begin{array}{l}\text { The air moves less pressure than silent air pressure, Ibrahim (2012: } \\
\text { 37). }\end{array}$ \\
\hline $\begin{array}{l}\text { Heavier objects will fall earlier than lighter objects when } \\
\text { dropped from the same height from the earth's surface (the } \\
\text { event of free fall). }\end{array}$ & $\begin{array}{l}\text { Both objects will fall simultaneously. The mass of matter has no } \\
\text { effect on the speed of free fall, what matters is gravity, Ibrahim } \\
(2012: 44)\end{array}$ \\
\hline $\begin{array}{l}\text { The red / purple and beautiful part of the Bogenville flower } \\
\text { is the crown. }\end{array}$ & $\begin{array}{l}\text { The brightly colored and attractive part of the bogenville plant is a } \\
\text { flower sheath. The real flower is inside the flower sheath. The } \\
\text { flowers are white with five petals, Ibrahim }(2012: 28) \text {. }\end{array}$ \\
\hline Cat's body is covered by fur. & The cat's body is covered by hair, Ibrahim (2012: 26). \\
\hline $\begin{array}{l}\text { Geckos feet and geckos have adhesive fluid that makes it } \\
\text { able to stick to the wall. }\end{array}$ & $\begin{array}{l}\text { Lizards use a spatulae to get into the atomic layer of the wall and } \\
\text { then bind firmly and hold the body to stick to the wall and can } \\
\text { walk easily. }\end{array}$ \\
\hline $\begin{array}{l}\text { Events of the emergence of water points on the outside of the } \\
\text { glass, comes from ice water that is on the inside of the glass. }\end{array}$ & $\begin{array}{l}\text { The points of water on the outside of the glass of ice water come } \\
\text { from the air around the glass which is condensing. }\end{array}$ \\
\hline Air / gas has no mass. & Although air is an intangible object, air has mass. \\
\hline
\end{tabular}

Table 2:- List of Concept Items

\section{The link between POE and Reduction of Misconception}

According to Leslie and Briggs (1987) learning science is best if the process is carried out as the science is found. Science is discovered through a scientific method that starts from compiling hypotheses, then making observations and or experiments. The POE steps are "miniature" of the scientific method. Therefore POE is an appropriate way to teach the concept of science without causing errors. POE can be used as a means to implement Piaget's theory of cognitive development and also constructivism learning theory. Besides POE also supports improving the quality of memory control of students in information processing.

Each stage of the POE learning strategy has an important role in reducing misconceptions that occur in students. Three main stages of POE namely predict, observe, and explain as an effort to reduce misconceptions have been compiled into RPP and LKPD in detail.

\section{METHODS}

This study was included in the Pre-Experiment research, with the design of One Group Pretest-Posttest which was implemented at the stage of reducing students' misconceptions.

\begin{tabular}{|c|c|c|}
\hline Pretest & Treatment & Posttest \\
\hline $\mathrm{O}_{1}$ & $\mathrm{X}$ & $\mathrm{O}_{2}$ \\
\hline
\end{tabular}

Sugiyono (2013: 112)

Table 3:- One Group Pretest-Posttest Design Pattern

This research was conducted at SDN Krembangan Selatan I, with the address No. Jalan Indrapura No. 34 Surabaya, which was held for one semester which was divided into several stages of time. Sampling in this limited trial if presented can be described as follows: the total number of class $\mathrm{V}$ is 47 students divided into 2 classes. From the 2 classes, 12 students were taken as research samples. Thus, the total number of students studied was $26 \%$ of the entire study population. Judging from the 
cognitive aspects of students' abilities in general and this class has never done learning using the POE strategy. The research steps include requirements analysis, compiling diagnostic tests and learning tools,

The research variables observed were the conception profile of students before and after learning and the reduction of misconceptions that occurred. The research instruments used included diagnostic tests, learning achievement sheets and constraints, and learning device validation sheets. Data collection techniques included validation, observation, and testing. Whereas data analysis techniques include analysis of the implementation of lesson plans and constraints, conception profile analysis, and reduction of misconceptions (tests of normality, homogeneity, t-test).

Finally, complete content and organizational editing before formatting. Please take notes of the following items when proofreading spelling and grammar:

\section{RESULTS AND DISCUSSION}

In this section presented the results of data analysis that has been obtained from research conducted at SDN Krembangan Selatan I. Data obtained in the study are the conception profile of students before and after learning, reduction of misconceptions and the implementation of lesson plans and constraints during learning.

\section{A. Analysis of Student's Conception Profile Before Learning}

The results of the analysis of the percentage of students' conception distribution at the time of the pretest ie understanding the concept, lack of concepts, misconceptions, and errors can be seen in the following table:

\begin{tabular}{|c|c|c|c|c|}
\hline \multirow{2}{*}{$\begin{array}{c}\text { Concept } \\
\text { Number }\end{array}$} & \multicolumn{4}{|c|}{ Percentage (\%) } \\
\cline { 2 - 5 } & MK & KK & MKS & E \\
\hline $\mathbf{1}$ & 8.3 & 8.3 & 83.3 & 0.0 \\
\hline $\mathbf{2}$ & 8.3 & 8.3 & 83.3 & 0.0 \\
\hline $\mathbf{3}$ & 58.3 & 0.0 & 41.7 & 0.0 \\
\hline $\mathbf{4}$ & 8.3 & 0.0 & 83.3 & 8.3 \\
\hline $\mathbf{5}$ & 16.7 & 0.0 & 75 & 8.3 \\
\hline $\mathbf{6}$ & 16.7 & 8.3 & 66.7 & 8.3 \\
\hline $\mathbf{7}$ & 16.7 & 8.3 & 50 & 25 \\
\hline $\mathbf{8}$ & 41.7 & 0.0 & 58.3 & 0.0 \\
\hline $\mathbf{9}$ & 8.3 & 0.0 & 58.3 & 33.3 \\
\hline
\end{tabular}

Table 4:- Percentage of Distribution of Conception during Pretest

Based on the above table, it can be described that the results of the misconception pretest occur in all the concepts being tested. The biggest percentage of misconception is in concepts number 1,2 , and 4, which are the pressure difference between stationary and moving air, the crown of the bogenville flower, and the shape of the gecko foot. The smallest percentage of misconception is in concept number 3 which is the difference between hair and hair in living things. Based on the analysis of the conceptual profile before learning with the POE strategy obtained an average of $67 \%$ of all students experiencing misconceptions for each concept item.

B. Analysis of Students' Conception Profile After Learning

The results of the analysis of the percentage of students' conception distribution at the time of the posttest ie understanding the concept, lack of concepts, misconceptions, and errors can be seen in the table as follows:

\begin{tabular}{|c|c|c|c|c|}
\hline \multirow{2}{*}{$\begin{array}{c}\text { Concept } \\
\text { Number }\end{array}$} & \multicolumn{4}{|c|}{ Percentage (\%) } \\
\cline { 2 - 5 } & MK & KK & MKS & E \\
\hline $\mathbf{1}$ & 83.3 & 8.3 & 8.3 & 0.0 \\
\hline $\mathbf{2}$ & 91.7 & 0.0 & 0.0 & 8.3 \\
\hline $\mathbf{3}$ & 91.7 & 8.3 & 0.0 & 0.0 \\
\hline $\mathbf{4}$ & 91.7 & 0.0 & 8.3 & 0.0 \\
\hline $\mathbf{5}$ & 83.3 & 8.3 & 8.3 & 0.0 \\
\hline $\mathbf{6}$ & 83.3 & 8.3 & 8.3 & 0.0 \\
\hline $\mathbf{7}$ & 75 & 8.3 & 16.7 & 0.0 \\
\hline $\mathbf{8}$ & 83.3 & 0.0 & 8.3 & 8.3 \\
\hline $\mathbf{9}$ & 91.7 & 0.0 & 8.3 & 0.0 \\
\hline
\end{tabular}

Table 5:- Percentage of Distribution of Conception at Posttest

Based on the data in the above table, it can be described that the results of the posttest after getting learning using the POE strategy, still found misconceptions on the 7 concepts tested namely concepts number 1, 4, 5, 6, 7, 8, and 9. Students who are still experiencing the largest percentage of misconceptions found in concept number 7 which is about free fall motion in a vacuum. Whereas at concept number 2 about the crown of flower Bogenville and concept number 3 about the difference in hair and hair in living things at posttest there is no misconception in students. Through this analysis, the conception profile after learning with POE strategies obtained an average of $7.4 \%$ of all research subjects experiencing misconceptions for each concept item.

\section{Analysis of Reduction of Students' Misconceptions}

Furthermore, the profile of misconceptions during the pretest and posttest was compared to determine the reduction of misconceptions. The results of the reduction in misconceptions experienced by students during the pretest and posttest are presented in the following table: 

follows:

Misconceptions, and errors can be seen in the table as

\begin{tabular}{|c|c|c|c|c|c|c|}
\hline \multirow{2}{*}{$\begin{array}{c}\text { Number } \\
\text { Question }\end{array}$} & \multicolumn{2}{|c|}{ Pretest } & \multicolumn{2}{c|}{ Posttest } & \multicolumn{2}{c|}{ Reduction } \\
\cline { 2 - 7 } & total & $(\%)$ & total & $(\%)$ & total & $(\%)$ \\
\hline 1 & 10 & 83.3 & 1 & 8.3 & 9 & 75 \\
\hline 2 & 10 & 83.3 & 0 & 0.0 & 10 & 83.3 \\
\hline 3 & 5 & 41.7 & 0 & 0.0 & 5 & 41.7 \\
\hline 4 & 10 & 83.3 & 1 & 8.3 & 9 & 75 \\
\hline 5 & 9 & 75 & 1 & 8.3 & 8 & 66.7 \\
\hline 6 & 8 & 66.7 & 1 & 8.3 & 7 & 58.4 \\
\hline 7 & 6 & 50 & 2 & 16.7 & 4 & 33.3 \\
\hline 8 & 7 & 58.3 & 1 & 8.3 & 6 & 50 \\
\hline 9 & 7 & 58.3 & 1 & 8.3 & 6 & 50 \\
\hline
\end{tabular}

Table 6:- Reduction of Students' Misconceptions

Table 6 shows a comparison of data on the number of students experiencing misconceptions during the pretest and posttest. The misconception profile after learning by using the POE strategy decreased the percentage of misconceptions. Reduction of misconception at posttest occurs in all concepts tested with different percentages. The highest reduction in misconception occurred in concept number 2, which is about the crown on the Bogenville flower. Reduction of misconceptions for the concept of $83.3 \%$. While the smallest reduction occurred in concept number 7 about free fall motion in a vacuum with a reduction percentage of $33.3 \%$.
Based on the discussion above it can be concluded that learning using POE strategies can reduce misconceptions among students.

In the next stage a series of hypothesis tests will be carried out consisting of a number of statistical tests including the normality test, homogeneity test, and Independent t-test using SPSS. The test will be described as follows.

\begin{tabular}{|c|c|c|c|c|c|}
\hline \multicolumn{3}{|c|}{ Kolmogorov-Smirnova } & \multicolumn{3}{c|}{ Shapiro-Wilk } \\
\hline Statistics & df & Sig. & Statistics & df & Sig. \\
\hline .99 & 12 & $.200 *$ & .919 & 12 & $\mathbf{2 7 6}$ \\
\hline
\end{tabular}

Table 7:- Normality test

Based on the table above, it can be seen that the significance in the Shapiro-Wilk column is $0.276>0.05$, so the conclusion can be drawn that the data is normally distributed.

\begin{tabular}{|c|c|c|c|}
\hline Levene Statistics & df1 & df2 & Sig. \\
\hline 3,745 & 1 & 22 & $\mathbf{. 0 6 6}$ \\
\hline
\end{tabular}

Table 8:- Homogeneity Test

Based on the table above, it can be seen that the significance value of the data is $0.066>0.05$, so it can be concluded that the data is homogeneous.

The results of the $t$ test for the pretest and posttest data can be seen in the following table:

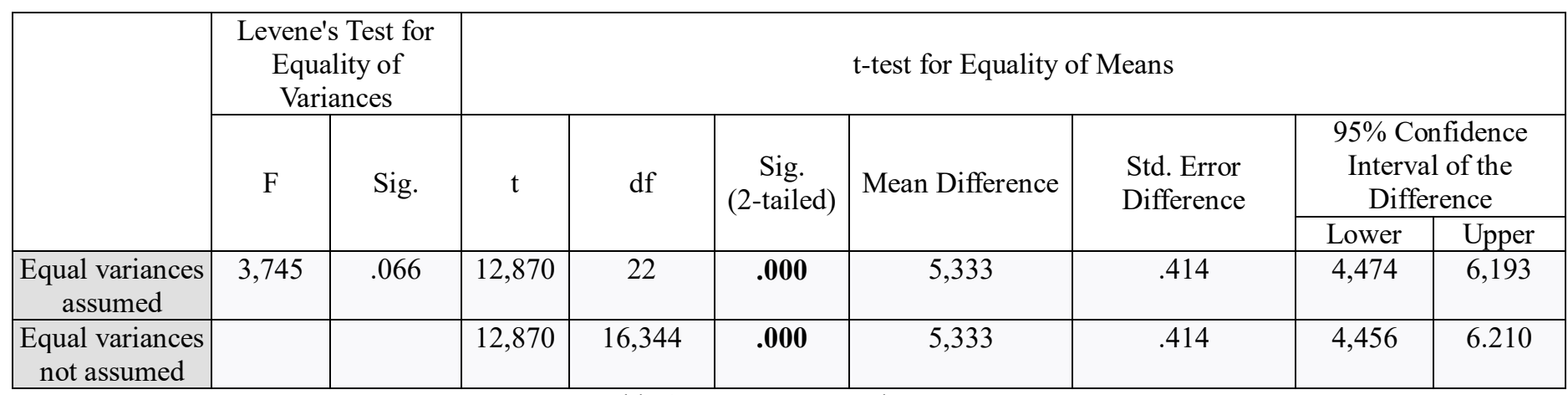

Table 9:- Test Pretest and Posttest

Based on the above table, it can be seen that for the number of misconceptions before and after learning by using the POE strategy, the probability value or Sig. (2tailed) $0.000<0.05$, it can be concluded that there is a significant difference between pretest and posttest. This shows that the average number of students' misconceptions after learning has decreased significantly compared to before learning.

\section{Analysis of the Implementation of RPP and Learning Constraints}

The reduction in misconceptions after learning certainly cannot be separated from the implementation of learning that is designed in such a way by using the POE strategy. Learning is carried out referring to the lesson plan that has been prepared at the research preparation stage.
The results of the implementation of the lesson plan that were observed by two observers based on the observation sheet during learning had a very good tendency with an average score of 3.9. The data analysis technique for the implementation of learning refers to Riduwan (2010: 15).

Analysis of obstacles or obstacles during the learning process is done through the observation method and written in the observation sheet. All obstacles found in learning have been overcome and given solutions. The earliest obstacle discovered by researchers was where an outbreak occurred which made it impossible for teachers and students to meet face to face to conduct teaching and learning activities. An alternative solution to overcome this obstacle is learning is done online. For diagnostic tests done online, learning takes place using the zoom 
application, so teachers and students can do video conferencing. At the time of learning the students are provided with LKPD which has been converted into PDF and can be downloaded by students. At the beginning of learning some students find it difficult with the POE stage because they have never carried out learning using this strategy before, especially when making predictions and conclusions. An alternative solution to overcome these obstacles is by giving students intense direction on POE learning especially in formulating predictions / hypotheses so that in the next stages the students do not experience difficulties. The next obstacle is that students are not accustomed to using the zoom application, so often the microphone is not muted, so the teacher's explanation is often disturbed by the sounds around the students.

\section{CONCLUSION}

Based on the analysis of the conception profile before learning with the POE strategy obtained an average of $67 \%$ of the entire research subjects experiencing misconceptions for each concept item. While the results of the conception profile analysis after learning with the POE strategy obtained an average of $7.4 \%$ of all research subjects experiencing misconceptions for each concept item.

Based on the analysis of the results of the calculation of misconceptions at the time of the pretest and posttest using the $t$ test, obtained the value of the probability or sig. (2-tailed) 0.000 which is smaller than 0.05 , meaning that there is a significant difference between the results of the pretest and posttest. This shows that the average number of students' misconceptions after learning has decreased significantly compared to before learning. So it can be concluded that, the application of POE learning strategies can reduce students' misconceptions on science subjects in elementary schools, force and motion, characteristics of living things, and objects or materials.

\section{REFERENCES}

[1]. Adebaya, Famakinwa., And Olufunke, Bello Theodora. 2015. Generative and Predict-ObserveExplain Instructional Strategies: Towards Enhancing Basic Science Practical Skills of Lower Primary School Pupils. International Journal of Elementary Education. Vol. 4, No. 4, 2015, pp. 86-92.

[2]. Banawi, Anasufi., Et al. 2019. Prospective Primary School Teachers' Conception Change in States of Matter and Their Changes through Predict-ObserveExplain Strategy. International Journal of Instruction. Vol 12, No. 3. PP. 359-374.

[3]. Berg, EVD 1991. Physics Misconceptions and Remediation. Salatiga: Satya Wacana Christian University.

[4]. Costu, B., Ayas, A., \& Niaz, M. 2011. Investigating the effectiveness of a POE-based teaching activity on students' understanding of condensation. Journal of Springer Science + Business Media BV, 40, 47-67.
[5]. Dahar, Ratna Wilis. 2011. Learning Theory and Learning. Jakarta: Erlangga.

[6]. Gernale, J., Duad, D., \& Arañes, F. 2015. The Effects of Predict-Observe-Explain (POE) Approach on the Students' Achievement and Attitudes Towards Science. The Normal Lights, 9 (2), 1 - 23.

[7]. Halim, Lilia., Yong, Tan Kia., Mohd Meerah, TS 2014. Overcoming Students' Misconceptions on Forces in Equilibrium: An Action Research Study. Creative Education, 2014, 5, 1032-1042.

[8]. Ibrahim, M. 2012. Concepts, Misconceptions, and How to Learn. Surabaya: Unesa University Press.

[9]. Kaltakci, Derya Gurel, et al. 2007. Identification of Pre-Service Physics Teacher's Misconception on Gravity Concept: A Study of a 3-Tier Misconception Test. Sixt International Conference of the Balkan Physical Union: American Institute of Physics.

[10]. Kubiatko, Milan., Prokop, Pavol. 2017. Pupils' Misconceptions about Mammals. Journal of Baltic Science Education. Vol. 6, No. 1, 2007, 5-14.

[11]. Kubiatko, Milan., Usak, Muhammet., And Pecusova, Eva. 2011. Elementary School Pupils' Knowledge and Misconceptions about Birds. Eurasian Journal of Educational Research. Issue 43, Spring 2011, 163182.

[12]. Lestari, Lusandra Dewi. 2018. Thesis: "Reducing Light Misconception by Using the Predict-ObserveExplain Strategy in Elementary Schools". Surabaya: Surabaya State University.

[13]. Liew, Chong Wah., And Treagust, David F. 1995. A Predict-Observe-Explain Teaching Sequence for Learning about Student's Understanding of Heat and Expansion of Liquids. Australian Science Teachers Journal. Vol. 41, No.1, March 1995, 68-71.

[14]. Mubarokah, Febriati Dian., Mulyani, Sri., And Indriyanti, Nurma Yunita. 2018. Indentifying Student's Misconceptions of Acid-Base Concepts Using a Three-Tier Diagnostic Test: A Case of Indonesia and Thailand. Journal of Turkish Science Education, v.15, n. Special Issue, December 2018, pp. 51-58, doi: 10.12973 / tused.10256a.

[15]. Ogunleye, BO and Babajide, VFT 2010. Effects of Predict-Observe-Explain Instructional Strategies on Students Practical Skills in Physics. International Journal of Continuing and Non-Normal Education, 7 (1), 1-18.

[16]. Pesman, H. \& Erylmasz, A. 2010. Development of a Three-tier Test to Assess Misconceptions About Simple Electric Circuit. The Journal of Educational Research. 102, p. 208-222.

[17]. Prodjosantoso, AK, Hertina, AM, \& Irwanto (2019). The Misconception Diagnosis on Ionic and Covalent Bonds Concepts with Three Tier Diagnostic Test. International Journal of Instruction, 12 (1), 14771488.

[18]. Dormitory, Ramon Sinkiriwang. 2015. Thesis: "Remediation of Science Misconception Electricity Material Using POE Strategy Assisted by PhET Simulation Media in Elementary Schools". Surabaya: Surabaya State University. 
[19]. Restami, MP, Suma, K., Pujani, M. 2013. "The Influence of the POE (Predict-Observe-Explain) Learning Model Against Understanding of Physics Concepts and Scientific Attitudes Judging from Student Learning Styles". e-Jornal Ganesha University Graduate School of Science Study Program. Volume 3. Pg. $1-11$

[20]. Rohmad. 2013. Development of the POE Learning Tool (Predict-Observe-Explain) to Reduce the Misconception of Science Misconception in Jetis Ponorogo Middle School (Unpublished master's education thesis). Surabaya State University.

[21]. Santoso, Singgih. 2014. Complete Guide to SPSS Version 20 Revised Edition. Jakarta: Elex Media Komputindo.

[22]. Sugiyono. 2013. Metode Penelitian Pendidikan: Pendekatan Kuantitatif, Kualitatif, dan R\&D. Bandung: Alfabeta.

[23]. Sulistyorini, Sri. 2007. Elementary School Science Learning. Semarang: Tiara Discourse.

[24]. Suparno, P. 2013. Misconceptions \& Concept Changes in Physics Education. Jakarta: PT Gramedia Widiasarana Indonesia.

[25]. Suwarto. 2013. Development of Diagnostic Tests in Learning. Yogyakarta: Student Library.

[26]. Tayubi, YR 2005. "Identification of Misconceptions in Physics Concepts Using the Certainty of Response Index (CRI)". Journal of Education Pulpit. No. 3 / XXIV / 2005. Thing. 5

[27]. Widiyanto, Joko. 2010. SPSS for Windows for Statistical Data Analysis and Research. Surakarta: FKIP UMS Publishing Board. 